\title{
Izabela Trzcińska*
}

AGH University of Science and Technology in Krakow

\section{Agata Świerzowska**}

Jagiellonian University in Krakow

\section{THE ORIGIN AND IMPACT \\ OF THE THEOSOPHICAL CENTRE IN ADYAR ${ }^{1}$}

\begin{abstract}
One of the most interesting examples of the Theosophists' campaign of transgressive imagination in Eastern and Western culture is the movement's headquarters - The Theosophical Society International Headquarters in Adyar (Chennai, Tamil Nadu), called the "vision of hope for mankind". This remarkable project has so far failed to attract any comprehensive research or permeate the extensive sources of Theosophical literature or subject literature. The aim of this paper is to highlight the most specific elements of this utopia - partly imagined, partially realised - which was intended by its creators to be an inspiration for the coming new era of the world.

Keywords: Adyar, Madras, Theosophical Society, Helena P. Blavatsky, Banyan, utopia, perennialism
\end{abstract}

The Theosophical Society was founded in New York on 17 November 1875. Among its founders were Helena P. Blavatsky (1831-1891) and Henry S. Olcott (1832-1907). This extremely charismatic and legendary couple attracted a number of outstanding artists and scholars to the ranks of the Theosophical Society (hereafter referred to as TS), thanks to which Theosophy had a significant influence on the shape of contemporary culture. Suffice it to say that various illustrious figures joined or sympathised with the TS, including Vassily Kandinsky (1866-1944), Paul Klee (1879-1940), Piet Mondrian (1872-1944), Lewis Carroll (1832-1898), William Butler Yeats (1865-1939), Thomas Edison (1847-1931) and Benjamin

* Corresponding author: Izabela Trzcińska, Wydział Humanistyczny AGH Akademii Górniczo-Hutniczej w Krakowie, ul. Gramatyka 8a, 30-071 Kraków; e-mail: trzcinska@agh.edu.pl;

** Corresponding author: Agata Świerzowska, Wydział Filozoficzny Uniwersytetu Jagiellońskiego, ul. Gołębia 24, 31-007 Kraków; e-mail: agata.swierzowska@uj.edu.pl.

1 This research was carried out within the framework of the Minister of Science and Higher Education's "National Programme for the Development of Humanities" for 2016-2019: Polish Culture in Relations to the Western Esoteric Philosophy in the Years 1890-1939 (0186/NPRH4/H2b/83/2016). 
Lee Whorf(1897-1941), whose famous article "Language, Mind and Reality" was published in 1942 in The Theosophist (Whorf 1942). It is, therefore, no exaggeration to say that Theosophical fascination translated into the development of a new concept of Western art as well as scientific notions that have contributed to shaping the cultural image of modernity ${ }^{2}$. At the same time, the Theosophical Movement was controversial right from the moment of its inception and remains so today, since its projects inextricably intertwine esoteric and avantgarde themes, and the search for cultural sources, often understood in a mythical sense, is associated with the desire to build a better world. In the Theosophists' belief system, this largely paradoxical intent was to liberate the imagination that conditioned progress in the transformation of the world.

One of the most interesting examples of the Theosophists' campaign of transgressive imagination in Eastern and Western cultures is the movement's headquarters - The Theosophical Society International Headquarters in Adyar, Chennai (previously Madras), Tamil Nadu, called the "vision of hope for mankind" by Curuppumullage Jinarajadasa (1875-1953), the fourth president of the TS (Neff 1999: 7). This remarkable project has so far failed to attract any comprehensive research or permeate the extensive sources of Theosophical literature or the subject literature, which includes, first and foremost, some well-developed studies on esotericism. In a short article it is impossible to even present an exact description of the Theosophical headquarters in Adyar, let alone forge a deeper interpretation of this cultural phenomenon. However, we aim to highlight the most specific elements of this utopia - partly imagined, partially realised which was intended by its creators to be an inspiration for the coming new era of the world.

\section{HISTORICAL OUTLINE OF THE CENTRE IN ADYAR}

According to the TS, from the very beginning an extraordinary role was played by the religious and philosophical traditions of the East. Even the Theosophist's chief maxim "No religion higher than truth" was that of the nineteenth-century maharaja of Benares (Varanasi) ${ }^{3}$. Helena P. Blavatsky openly claimed that her teachings inspired her mysterious travels in the Himalayas. So soon after the founding of the society, she set out with Henry S. Olcott to India in search of a suitable location for the TS headquarters, so that it might become a true centre

2 The idea of theosophy has ancient roots, and truly came to life in Europe in the sixteenth and seventeenth centuries (Faivre 2000). This primordial Christian adaptation of theosophy has been largely transformed in the edicts of TS leaders. The structures of this Society became widespread in the late nineteenth and twentieth centuries in many countries of the world, flourishing in the interwar period that served to popularise Theosophical beliefs (cf. Campbell 1980; Carlson 1993; Godwin 1994; Goodrick-Clarke 2010; Rudbøg 2010). Modern Theosophy initiated by Helena P. Blavatsky's teachings became the starting point for New Age spirituality (cf. Hanegraaff 1998; Hanegraaff 2013; Hammer 2001).

3 This is a translation of the Sanskrit satyān nāsti paro dharmah which translates exactly as "there is no dharma higher than truth". The root meaning of the term dharma, however, goes beyond that which is most commonly used and accepted by the Theosophists, and is associated with "religion". Dharma is: order, law, duty, behaviour, and action according to the eternal order of things ( $r t a)$, cf. for example Monier Williams Sanskrit-English Dictionary (2008 revision), on-line: http://www.sanskrit-lexicon.uni-koeln.de/monier/ [11.10.2017]. 
of spirituality and inspiration. On 16 February 1879, Blavatsky and Olcott arrived in Bombay (Mumbai), where they founded the first Theosophical centre in India. In 1882, however, Olcott decided to purchase a relatively small estate - The Huddleston Gardens - founded in the second half of the 18th century and stretching along the southern bank of the Adyar River, right at its mouth on the Bay of Bengal, where The Theosophical Society International Headquarters was established. Soon, many legends were born concerning this choice, with rumours of some mysterious Masters, as well as numerous fortunate coincidences that occurred in their quest for the new seat of the Theosophists ${ }^{4}$. The phrase repeated by Blavatsky - the "Master wants this purchased" (Neff 1999: 2, Groves 1950: 2) - was to become the founding motto of the venture. It was also acknowledged that Adyar had a slightly better climate than the centre of Madras, which Blavatsky called a "Dravidian hell" (Bławatska 2005: 9). The relatively close proximity of the Nilgiri Hills, where the hottest part of the year was spent, was also important, as it was then linked to Madras by rail.

The property was purchased, along with its existing infrastructure. Many of its components now no longer exist (e.g. the stables and a swimming bath) or they have been converted (e.g. a tank became a tennis court and a garden pavilion now functions as the guest house) (Neff 1999: 2). However, two buildings that have survived to this day from the very beginning played important roles - they became the "heart" of Adyar. The first is the large main bungalow which, after many modifications and redevelopment, now functions as the Main Headquarters Building. This initially housed the office of the Recording Secretary, and the office of the manager of The Theosophist. In this building is also the room where Blavatsky held office, and where one of the Mahatmas would visit her daily ${ }^{5}$. The conversion of this section began in 1883, when another room was added here, called "Morya's room", later followed by "the Occult Room". In the immediate vicinity of these interiors there was also the first chapel, which would provide the backdrop for many supernatural phenomena - here the famous Mahatmas would leave their letters addressed to the Theosophists, and it was here that illnesses would be inexplicably cured and those who found themselves in this space would find solutions to their problems (Krishnamurti 1911: 4).

However, it must be emphasised that the property in Adyar was not only intended for the founders of the movement. The desire of the leaders was also that there should be systematic "universal" conventions for the members of the society, which, admittedly, was an extremely bold idea at the time. The first such meeting was held in 1882 in a palm leaf tent erected near the headquarters (Krishnamurti 1911: 5). In order to prepare a better place for communal meetings, in 1885 the Main Headquarters Building was rebuilt, including the T-shaped Main (or Great) Hall, which is still the site of the Annual Conventions today as well as other ceremonies such as daily prayers (such as the "Prayers of the Religions" initiated in 1925 by Jiddu Krishnamurti (1895-1986), the commemoration of the death of the founders of the TS, lectures, etc). A year later, a library room was added to this complex (due to the

\footnotetext{
4 For a detailed description of the purchase of The Huddleston Gardens see (Chetty 1926).

Theosophists believed that they had contact with the Masters who were beyond time but in various ways influenced the evolution of mankind (Johnson 1994; Goodrick-Clarke 2010).
} 
exterior decoration of the walls with eight elephant heads, it was commonly referred to as the "Elephant Building", which today houses a museum ${ }^{6}$ ), as well as two rooms that were added on the first floor above the library, initially used by Blavatsky, and still available today for the Presidency of the TS. The other important building of the original premises is known as the Octagonal Bungalow, first occupied by Olcott and then for many years by Charles W. Leadbeater. It was also here that "much of his occult work was done" (Groves 1950: 6), and the Theosophist was often visited there by Master K.H.

From the beginning, the "mighty Banyan Tree" (Neff 1999: 25) became a very important area within the grounds of the estate. The Ficus benghalensis is recognised in India as a sacred tree and can often be found near places of religious or spiritual significance. The banyan tree is a typical arbor mundi, whose spreading crown is lost in the heavens; the trunk, or rather its innumerable offshoots, represent the material world while the roots form its base. This tree is characterised by its extraordinary longevity and the ability to lay down new trunks that occupy ever more space over time. Thus, the banyan also symbolises the eternal and infinite power of life. Under the banyan tree, important mythic figures (such as Shiva and Krishna) and religious reformers (such as Buddha) rested, taught and meditated and in its shadow dwell their spirits. Significantly, in the context of complex deliberation, the banyan tree is identified as a tree of wisdom - "It is said that there is an imperishable banyan tree that has its roots upward and its branches down and whose leaves are the Vedic hymns. One who knows this tree is the knower of the Vedas" - so Krishna instructed Arjuna, his disciple and follower (Bhagavadgita 15.1).

This symbolism of the banyan as a tree of life and knowledge was adopted by the Theosophists. The Great Banyan in Adyar became the embodiment of Divine Life and Divine Wisdom. "The Divine Life manifesting through it [i.e. the banyan tree] acquires a distinct personality; and sometimes this externalizes itself, and becomes clearly visible to clairvoyant sight as a cloudy human form [...] with a gentle but majestic expression," claimed Leadbeater (cited in Neff 1999: 25). Divine Wisdom would adopt a more material form when under the Banyan Tree each new TS president would conduct the "Twilight Talks" later published in The Theosophist. TS leaders would also meet here and teach, drawing students and people working in Adyar into conversations and discussions.

Over time, the area of the Theosophical estates in Adyar was significantly expanded, and new buildings for public and private use also sprung up, including important villas dedicated to the leaders of the movement. The second president - Annie Besant (1847-1933) - made a major contribution to the development of the TS International Headquarters in Adyar. This extremely committed Theosophist-cum-feminist - with clear left-wing views and a supporter of an independent India (Prescott 2008) - put a great deal of effort into the development and operation of Adyar. Blavatsky spent relatively little time near Madras, because she fell persistently ill due to the local climate. On the other hand, Besant felt truly at home in India and was ready to transform it. She decided to create better living conditions for the people

${ }^{6}$ At present the library collection is housed in a separate building constructed as late as 1966 . The Main Headquarters Building houses archives and museum collections. 
who resided permanently in Adyar - primarily students and volunteers. In 1908 she purchased two large estates, today known as Blavatsky Gardens and Olcott Gardens.

In the first of the gardens Leadbeater Chambers was built, and it still exists today, offering Western style accommodation and a Bhojanasala (an Indian style canteen), while the other garden featured the impressively sized Olcott Bungalow. Two years later, the TS estate expanded once more - Besant bought a plot then named Besant Gardens, and in 1909 another piece of land, Besant Grove. During this time, a the TS member donated the Damodar Gardens and a piece of land known as Alsace Grove. Adyar's grounds also included purely functional facilities (such as private residences, a dispensary, electrical and maintenance buildings, a laundry room, hostel, etc.). Finally, under the Besant leadership, the area of Adyar increased from 27 acres to 263 (Krishnamurti 1911: 7) and the centre assumed its present shape ${ }^{7}$.

In 1917, Besant made another important decision - she marked and consecrated the place where the ashes of all TS presidents (with the exception of Blavatsky) would be scattered, and the bodies of some presidents would also be cremated there. This Garden of Remembrance contains a memorial shaped like the TS emblem - triangles interlocking to form a star with lotus ponds. On the walls of the triangles there are lists of the names of individual TS presidents. This place should not be regarded as a cemetery. Instead, in the vision of the Theosophists, it is a place that symbolises the community and the eternal permanence of pure wisdom, whose exhibitors and guardians were thought to be the presidents of the TS.

\section{THE SOURCE OF THEOSOPHIC UTOPIA}

The extensive and multi-faceted activity of the Theosophical Centre in Adyar is a unique phenomenon. However, its existence can be viewed in the context of the European tradition of utopia that is inseparable from modern esotericism - starting from the inspirational hermeticism of the work of Thomas More (1478-1535) (Yates 1991: 185-187), then moving on to the social concepts of Johann Valentin Andreae (1586-1654) that arose from the circle of

\footnotetext{
Currently the site includes 42 buildings with a variety of functions. A detailed, interactive map of contemporary Adyar can be found at http://www.global-theosophy.net/theosophical_society_map_1_large_5.php [retrieved: 15.03.2017] along with the location of the following places: 1 . The Theosophical Society Headquarters Adyar; 2a. Private residence; 2b. The Octagonal Bungalow; 3. The Arundale House; 4. The Main Gate (and TS Adyar Bookshop); 5. The Adyar Theatre; 6. The Administration Building; 7. The Buddhist Temple; 8. Jain Temple; 9. Bhojanasala (Indian style canteen); 10a. New Quadrangle; 10b. Old Quadrangle; 11. Bharat Samaj Hindu Temple (Temple of Light); 12. Zoroastrian Temple; 13. The Sikh Temple; Two semi-detached private residences; 15. Blavatsky Bungalow; 16. Banyan Tree; 17. Upasika; 18. St Michael and All Angels - Liberal Catholic Church; 19a. Leadbeater Chambers (LBC); 19b. The Western style restaurant; 20. Garden of remembrance. 21. Sevashrama - private residence; 22. Private Residence and Foundation for Jewish Synagogue nearby; 23. The Mosque. 24. Parsi Quarters - private residence; 25. Shanti Kunj (old name: Bell Bungalow); 26. Olcott Bungalow and Olcott Gardens; 27. Co-Masonic Temple; 28. Besant Scout Camping Centre; 29. Electrical and Maintenance Departments; 30 Adyar Library and Research Centre; 31. N.K.T. - National College for Education of Women; 32. Main Gate by car; 33. Vesanta Press; 34. TPH (The Theosophical Publishing House); 35. Laundry; 36. HPB Hostel; 37. Sri Ram Colony; 38. Olcott Memorial High School; 39. Blue Cross - Hospital for Animals and more; 40. The School KFI (Krishnamurti Foundation India); 41. KFI School Entrance; 42. Dispensary.
} 
Rosicrucian ideas and the New Atlantis of Francis Bacon (1561-1626) (Yates 1972). All these cases involve a specific synthesis of the vision of the ideal community, the innovative development of science and alternative forms of spirituality. The turn of the nineteenth and twentieth centuries was a time of great revival for similar projects, the most famous of which was the establishment of the headquarters of the two greatest Societies - the Theosophical Society of Adyar and the Anthroposophical Society of Rudolf Steiner (1861-1925) in Dornach. Yet, it is also worth mentioning "Urusvati" - The Institute of Himalayan Studies initiated by Elena (1879-1955) and Nikolai Roerich (1874-1947) or George Ivanovich Gurdjieff's (1866-1949) Institute of Château Le Prieuré at Fontainebleau-Avon. In a similar vein, Auroville - The City of Dawn - came into existence much later at a location near Pondicherry, but its vision is rooted in the same kind of utopian thinking, as the purpose of all these more or less formalised fraternities, communities and associations was the general renewal of a given group, nation and, ultimately, humanity. Significantly, many of these utopias found their home in India.

One might consider that India, which after the Enlightenment had functioned in the universal imagination as a centre of pure wisdom undisturbed by the advancement of history, was earmarked as a special place suitable for the realisation of such undertakings. The critique of modernity articulated in the era of Romanticism used the image of India in its narrative as a land rich in spiritual values and radically different from the dysfunctional - i.e. extremely rationalised - Western world (Halbfass 1990: 69ff.). These motifs were adopted and used by the esotericists as they built their utopian visions at the turn of the century, including the most influential Theosophical currents. It was Blavatsky and Olcott who resurrected the old, yet still enlightened, idea of the original revealed Indian wisdom, and reformulated it so that it could become a kind of sign of opposition to, as they considered, the spiritually dead West. The location of where the gradual improvement of humanity would take place marked, on the one hand, a break with a civilisation without a future and, on the other, a symbolic and actual return to the "sources of life".

It is worth noting that numerous testimonies of utopian ideas may also be found in Polish culture, although they rarely left the drawing board. One of the first was Mieczysław Geniusz's (1853-1920) idea of an esoteric centre to be built near Krakow (Przewóska-Helja 1937: 51-53). One may recall the Brotherhood of the National Revival of Karol Chobot (1886-1937), Eugeniusz Polończyk's (?-1924) “Arja” Association or Wincenty Lutoslawski's (1863-1954) "Eleusis", an association that planned to create a settlement where it would be possible to achieve the ideal of a brotherhood. It is also worth mentioning that one of the few esoteric centres that came to fruition in Poland was a holiday centre in Mężenin, run by the Polish TS in 1925-1939. Most of these projects did not progress beyond the planning stage, but it is hard to resist the impression that the conception of these fraternities and the definition of their agenda (as far as the plans at all assumed the establishment of a particular centre) were only part of a broader whole, in which these places functioned in the minds and imaginations of their creators or users. It seems that on this level, these centres, or rather the imagination of them, achieved their essential utopian purpose - to quote Zygmunt Bauman: "a horizon constantly on the move, perpetually receding but guiding the travel or like a spike prodding the conscience, a nagging rebuke that cast complacency and self-adoration out of bounds and out of question. Injured, humiliated" (Bauman and Tester 2001: 49). The essence of utopia 
understood in this way is that it does not have to be fully realised; it can merely remain a project that undergoes a constant quest for perfection and a tireless response to the hope of building a better world. In the context of these sometimes vague and unrealistic concepts, the establishment of the Theosophical centre in Adyar was an impressive feat, especially since it is closely related to the fundamental assumptions of the TS. In the Theosophical tradition, two expressive aspects emerge, the first being the shaping of a specifically understood spirituality. The second is related to social demands - extremely important in the Theosophical environment. In the Adyar project, both of these goals were achieved.

\section{THE THEOSOPHICAL PROGRAM OF SPIRITUAL RENEWAL}

The Theosophists did not intend to create a new religion. They preferred to refer to the idea of a universal religion, for which individual beliefs are merely historical manifestations. The basic message of the Theosophists was based on the idea of perennialism ${ }^{8}$. This concept is presented in the iconographical program of the large hall of the aforementioned Main (or Great) Hall at the headquarters, which "forms a veritable universal shrine since its walls are decorated with symbols representing eighteen different religions, in addition to Freemasonry and of course Theosophy" Groves 1950: 25). Images of the founders of important religions, as well as their associated symbols, are placed here, including: Zarathustra, Gautama Buddha, Jesus Christ, Moses, Krishna, a verse from the Qur'an, symbols of Shintoism, Lao-tze, Confucius, Osiris, Orpheus, Mithra, Istar, Mahavira, Guru Nanak, Quetzal-Coatl, and Baha Ullah. Next to the entrance there is a plaque commemorating the creation of several dozen national sections of the society together with the dates of their establishment (including the Polish Theosophical Society, founded in 1923). The opposite side, next to the entrance to the library (today's museum), features performances of the goddesses of Wisdom: the Roman Minerva and Indian Saraswati. In the large hall there are also some large sculptures of Blavatsky (under which some of her ashes were placed) and Olcott.

The living sign of this spirituality specific to the Theosophists are the nine places of worship constructed in the area of Adyar: Bharat Samaj Hindu - The Temple of Light (1915), a Buddhist temple (1925), St. Michael and All Angels Liberal Catholic Church (1925), a Mosque (1937), a Co-Masonic Temple (1908), a Jain temple (?), a Zoroastrian temple (?), and a Sikh temple (? $)^{9}$ as well as Jewish Synagogue which was never built and halted at the foundations, most probably for financial reasons (Huss 2015: 26). In the existing temples there are occasional rites. However, only the Hindu temple offers daily practice for the residents of the Adyar centre and its guests.

\footnotetext{
8 The TS members were supporters of perennialism - the concept of a common source of all religions, and also philosophical concepts that remain alive in various forms of belief, subject to cultural change. The origin of this concept should be sought in renaissance hermeticism, indicating biblical compatibility with the teachings of other religions. Finally, the idea of philosophia perennis was developed by Agostino Steuco in the sixteenth century (Schmitt 1966). In the teachings of the TS, perennialism - associated with the concept of the Ancient Wisdom - adopted a new form precisely because of the focus on the teachings of the East, which in this interpretation took on the functions previously reserved for the Judeo-Christian tradition (Besant 1897).

9 At this stage of the research the dates of foundation were not possible to establish.
} 
Adyar was thus conceived and designed as a place expressing and somehow enabling the practical experience of the unity of all religious traditions, and the discovery of their deepest and ultimate message - the Truth. Undoubtedly, the individual religious objects played an important role here, but their significance only emerges fully when they are considered in the context of the garden itself. The inspiration for its formation are threefold. Firstly, the garden itself, its style and arrangement, can be characterised as "South Indian Victorian" (Srinivas 2015: 75). This vision combined the European paintings of arcadia with South Indian horticultural gardens and scrub jungle - a plant formation typical of this region ${ }^{10}$. This form of garden is largely down to the above-mentioned Curuppumullage Jinarajadasa, who placed particularly strong emphasis on the "pedagogical" value of the natural environment. Incorporating religious elements or the symbols of various traditions would underline their vitality as well as their unity, a certain universal community - the second of the inspirations behind the gardens of Adyar. This community - and here we come to the third source of inspiration - included, in the opinion of Curuppumullage Jinarajadasa, not only human beings but all living things. The Theosophical centre in India was supposed to be a "forest fraternity" (Srinivas 2015: 75) like a Buddhist sangha - a living community in which all creatures would develop in harmony and work together for their mutual benefit. As so happened in the realisation of this utopia, Adyar "offers a place of contrast to a degenerating world, a place where the question of knowledge and freedom can be explored in relationship to the environment, seasons, open air, trees and other beings" (Srinivas 2015: 85).

It is no wonder that Adyar was compared to paradise - that is, a place of undisturbed harmony between people and nature, a place where heaven meets the earth and where supernatural powers abound. A literary testimony of the significance of this Theosophical centre can be found in a 1921 poem by Ernest Armine Wodehouse (1879-1936), Theosophist, poet and tutor of Jiddu Krishnamurti, which describes Adyar as follows:

[...] - I hail'd thee Paradise;

Fair emerald set 'mid sapphire seas and skies;

A Queen in green and blue; a bright leaf torn

From heaven's own book, that on an Earth forlorn

Had flutter'd down and settled; a rich prize

Won in some ancient strife with deities,

And thenceforth aye in friendship's token worn.

$[\ldots]$

Thy groves and flowers,

Bright river and pure skies - these have their part

In thy commingled charm. Yet are there Powers

Whose Presence binds thee nearer to each heart.

This is our Home - and yet it is not ours!

(Wodehouse 1921: 128)

10 For more information about Madras "garden houses" (including the Theosophical Society properties) cf. (Sriram 2008; Sudyka 2009). 
To emphasise the special nature of this assumption, the Adyar centre was considered as an ashram where one must not hurt, let alone take the life of animals or humans. This program was associated with the assumption of individual work on oneself, leading to the liberation of oneself from the "narrow drawers of one's own incarnations". The presence and teaching of Jiddu Krishnamurti - recognised by the Theosophists as a prophet, poet, and Messiah of the coming age (Venakatachalam 1940: 127-133) - was an extremely important aspect of the image of the centre as a chosen place. His resignation from this position in 1929 (Lutyens 1975: 272) was the cause of the first serious crisis among TS members.

\section{COMMUNITY WORK IN ADYAR}

Adyar was not only seen by its founders as merely a centre of renewal at a spiritual level. Equally important was its social program, linked inextricably to spiritual practice. The TS was open to people regardless of gender, race and religious beliefs, and its most important goal was to work to abolish the unjust differences between people. The realisation of this program was another challenge for Adyar, known for its extensive charity work and the tireless contribution of Theosophists to their quest to change the world. Particular emphasis was placed on the development of pedagogy. It is worth recalling that in Adyar, Maria Montessori (1870-1952) began her practice with a desire to create a teaching system that would prepare and shape a new person to undertake the task of transforming reality. Particular emphasis was placed on a form of development consistent with the child's individual predispositions and with his or her emotional needs ${ }^{11}$.

Adyar conducts extensive educational activities to this day. This is not just about the School of the Wisdom launched in 1964 by Curuppumullage Jinarajadas, whose goal even to this day is to "bring every student to life from the centre", dedicated to the development of people already involved in the TS as well as those who would like to become members of the society. From the very beginning, Adyar conducted multifaceted activity directed "externally" with the aim of providing a foundation to prepare people for further transformation and selfimprovement. As George S. Arundale (1878-1945), the third president of the TS, wrote: "We Theosophists know perfectly well that we have many planes of consciousness on which to stand up for right and against the wrong and we should be active on every plane we can contact" (Arundale 1939: 4). Universal and multidisciplinary education was one of these planes. Adyar, with the invaluable help of TS members, hosts the Besant Scout Camping Centre, the National College for the Education of Women, the Olcott Memorial High School, and the School KFI (Krishnamurti Foundation India). Nor should it be forgotten that it was in Adyar that Rukmini Devi Arundale (1904-1986) - George S. Arundale's wife - began her activity. Between 1936-1948, on the Theosophical campus she ran a school of music and Kalakshetra dance, now known internationally (Meduri 2005).

11 Helena P. Blavatsky frequently addressed issues of education in her texts (e.g.: Blavatsky: Theosophy and Education). 
Publishing was one of the aspects of the Adyar Centre's extensive educational activity. The purpose of this work was primarily to spread Theosophy - "sending forth theosophy throughout the world" (Arundale 1939: 6). The beginning of this activity was marked by the transfer of The Theosophist's editorial board from Bombay to Adyar in 1883. In 1908, Annie Besant initiated the establishment of Vassanta Press, which has so far published more than 700 Theosophical publications, as well as many on related topics. The publisher has also published numerous widely available titles: "The Theosophical World", "The Young Theosophist", "New India", "The Morning Star" and "The Adyar Library Bulletin".

Adyar's founding intent was to become a centre for art and science, a kind of living Theosophical museum, and the theme that tied the collections together was to be the belief central to Theosophy - of the existence of (and possibility of knowing) the eternal truth manifested in various ways throughout history. This thought was the impulse that pushed Henry S. Olcott to gather rare manuscripts representing various Indian spiritual traditions ${ }^{12}$, and in time, generally, publications on issues of broadly understood spirituality and religiosity. Likewise, the Adyar Museum is home to countless items of memorabilia donated by the founders and leaders of the TS in addition to the many artefacts from various parts of the world given by members and supporters of the TS (which, in various ways, manifested the "eternal truth", as the donors thought). These included objects that were thought to have been materialised by Helena P. Blavatsky, and the letters sent to her by the Mahatmas. The museum also features the famous painting "The Messenger", which Nikolai Roerich personally brought to Adyar in 1925, convinced that it would initiate a collection of contemporary art inspired by Theosophical thought.

Descriptions of the Theosophical Adyar from the 1920s show that Besant's dream came true when the Theosophical centre was transformed into a self-sufficient settlement in which the principles of equality and fraternity were indeed respected. One traveller wrote: "Adyar is a self-contained colony, its residents are pioneers in various kinds of activities. It is an international center, and therefore, of cosmopolitan character; a place of experiment of a great ideal. Men and Women, Hindu and Christian, British and Indian, youth and age try here to love - Brotherhood. [...] Adyar is a beauty-spot [...] Adyar activities are worldwide and cover all kinds of human endeavour, politics, education, art, science and religion" (Venakatachalam 1940: 128-129). Thanks to these guiding principles, Adyar appeared to be a king of a "miniature world" (Venakatachalam 1940: 130).

Theosophical Adyar also had a unique significance for the Hindus involved in its development. It is hard to resist the impression that when Arundale (1941) spoke of the "India of my dreams", his vision of a liberated country was inspired by Theosophical concepts. This is even more evident in Gokhale's (1944) essay of the same title, in which he even writes about the need to promote a community that would be referred to as "Catholic" in the Theosophical way - i.e. universal. It is tempting to reach the conclusion that this narration, full of faith in the fulfilment of dreams, paved the way for future change - dreams emerged from the realm of fantasy and became an important factor for transformation, as in another famous dream speech by Martin Luther King.

12 Today the library in Adyar has one of the largest collections of Indian manuscripts in the world, including some written on palm leaves. 


\section{CONCLUSION}

Theosophical Adyar, as an ideal model for social change, was to be the beginning of a new humanity reborn, the harbinger of a New Era, and a catalyst for the universal evolution of humanity. Thus, the organisation was to serve the self-sufficient community that was fully up and running during the Besant period and that of the next president - Jinarajadasa. The Theosophical centre in Adyar was, however, built primarily for the future. Paradoxically, after the Independence of India, the activity of the Theosophists began to decline in this country. The Theosophical centre still functions today, although it has become a kind of hortus conclusus, a closed garden of medieval legends, hidden from the outside world and somewhat forgotten. Nevertheless, Adyar remains a living testimony to the creative influence of Theosophy in the history of culture, as well as an example of a living, breathing utopia, where for some time the dream came true of a world in which everyone may feel free and fulfilled.

\section{REFERENCES}

Arundale, George S. 1939. Adyar, Adyar: The Theosophical Publishing House.

Arundale, George S. 1941. India of my dreams, Adyar: Vassanta Press.

Bauman, Zygmunt and Tester, Keith. 2001. Conversations with Zygmunt Bauman, Cambridge: Polity Press.

Besant, Annie. 1897. The Ancient Wisdom. An Outline of Theosophical Teachings, Adyar, Madras: Theosophical Publishing House.

Bławatska, Helena. 2005. Dziwy Indii, Warszawa: Wydawnictwo LOKA.

Blavatsky, Helena P. (no date). Theosophy and Education, Bombay: Theosophy Company (India) LTD.

Campbell, Bruce F. 1980. Ancient Wisdom Revived: A History of the Theosophical Movement, Berkeley: University of California Press.

Carlson, Maria. 1993. No Religion Higher than Truth: A History of the Theosophical Movement in Russia, 1875-1922, Princeton: Princeton University Press.

Chetty, Soobiah. 1926. The Purchase of Adyar Headquarters: A Reminiscence of H.P.B., "The Theosophist", March, pp. 741-747.

Faivre, Antoine. 2000. Theosophy, imagination, tradition: studies in Western Esotericism. SUNY series in Western esoteric traditions, tr. Christine Rhone, Albany, NY: State University of New York Press.

Gokhale, Gopal K. 1944. India of my dreams, Karachi: Star Publishing House.

Godwin, Joscelyn. 1994. The Theosophical Enlightenment. Albany: State University of New York Press.

Goodrick-Clarke, Nicholas. 2004. Helena Blavatsky, Berkeley: North Atlantic Books.

Goodrick-Clarke, Nicholas. 2010. The Coming of the Masters: the Evolutionary Reformulation of Spiritual Intermediaries in Modern Theosophy, in: Andreas B. Kilcher, Constructing Tradition: Means and Myths of Transmission in Western Esotericism, Leiden: Brill, pp. 113-160. 
Groves, C.R. 1950. Adyar, Adyar: The Theosophical Publishing House.

Halbfass, Wilhelm. 1990. India and Europe. An Essay in Philosophical Understanding, Delhi: Motilal Banarsidass Publishers.

Hammer, Olav. 2001. Claiming Knowledge: Strategies of Epistemology from Theosophy to the New Age, Leiden and Boston: Brill.

Hanegraaff, Wouter. 1998. New Age Religion and Western Culture: Esotericism in the Mirror of Secular Thought, Leiden: Brill, State University of New York Press, Albany.

Hanegraaff, Wouter. 2013. Western Esotericism: A Guide for the Perplexed, London: Bloomsbury.

Huss, Boaz. 2015. A Jew Living in an Ashram: „The Spiritual Itinerary” of S.S. Cohen, "Journal of Indo-Judaic Studies" 15: 20-29, https://www.academia.edu/31060166/ A_Jew_Living_in_an_Ashram_The_Spiritual_Itinerary_of_S.S_Cohen [5.04.2017].

Johnson, Paul K. 1994. The Masters Revealed: Madame Blavatsky and Myth of the Great White Brotherhood Albany, New York: State University of New York Press.

Krishnamurti, Jiddu (Alcyone). 1911. Adyar. The Home of the Theosophical Society, Adyar, Madras: The Theosophist Office.

Lutyens, Mary. 1975. Krishnamurti: The Years of Awakening, New York: Farrar Straus and Giroux.

Meduri, Avanthi (ed.). 2005. Rukmini Devi Arundale (1904-1986). A Visionary Architect of Indian Culture and the Performing Arts, Delhi: Motilal Banarsidass.

Monier Williams Sanskrit-English Dictionary (2008 revision), http://www.sanskrit-lexicon. uni-koeln.de/monier/ [11.10.2017].

Neff, Mary. 1999. Adyar. Historical Notes and Features up to 1934, Adyar and Wheaton: The Theosophical Publishing House.

Prescott, Andrew. 2008. 'Builders of the Temple of the New Civilisation': Annie Besant and Freemasonry, in: Alexandra Heidle and Jan A.M. Snoek (eds.), Women's Agency and Rituals in Mixed and Female Masonic Orders, Leiden: Brill, pp. 359-392.

Przewóska-Helja, Maria Cz. 1937. Mieczysław Geniusz. Dzieje żywota z kart pamiętnikowych, Warszawa: F. Hoesick.

Rudbøg, Tim. 2010. Helena Petrovna Blavatsky's Esoteric Tradition, in: Andreas B. Kilcher, Constructing Tradition: Means and Myths of Transmission in Western Esotericism, Leiden: Brill, pp. 161-177.

Schmitt, Charles B. 1966. Perennial Philosophy: from Agostino Steuco to Leibniz, "Journal of the History of Ideas" 27, 4: 505-506.

Srinivas, Smriti. 2015. A Place for Utopia: Urban Designs from South Asia, Seattle and London: University of Washington Press.

Sriram, Venkatakrishnan. 2008. Historic Residences of Chennai, Chennai: Chandra Sankar.

Sudyka, Lidia. 2009. Cennapuri - a city of gardens as described in the Sarvadevavilasa and the remnants of the gardens and Garden Houses today, "Padanus", 3, 1, "Nature in Literature, Art, Myth and Ritual": 105-127.

Venakatachalam, Govindraj. c.1940. Travel Diary of an Art Student (Men and Monuments), The Modi Power Printing: Bangalore.

Whorf, Benjamin Lee. 1942. Language, mind, and reality, “The Theosophist” 63, 1: 281-291. 
Whorf, Benjamin Lee. 1942. Language, mind, and reality, "The Theosophist" 63, 2: 25-37. Wodehouse, Ernest Armine. 1921. Adyar, "The Theosophist", November: 128.

Yates, Frances A. 1991. Giordano Bruno and the Hermetic Tradition, Chicago - London: The University of Chicago Press.

Yates, Frances A. 1972. The Rosicrucian Enlightenment, London: Routledge.

\section{POWSTANIE I ZNACZENIE TEOZOFICZNEGO CENTRUM W ADYARZE}

Jednym z najciekawszych przykładów działania transgresyjnej wyobraźni teozofów w kulturze Wschodu i Zachodu stała się główna siedziba ruchu, czyli The Theosophical Society International Headquarters in Adyar (Chennai, Tamil Nadu), nazwana „wizją nadziei dla ludzkości”. Ten niezwykły projekt nie doczekał się do tej pory żadnego kompleksowego opracowania ani w niezwykle szerokim nurcie źródłowej literatury teozoficznej, ani w literaturze przedmiotu, do której należy zaliczyć przede wszystkim znakomicie rozwijające się obecnie studia nad ezoteryzmem. Celem artykułu jest podkreślenie najbardziej specyficznych elementów tej utopii, po części wyobrażonej, po części zrealizowanej, która w zamierzeniach twórców miała stać się inspiracją dla nadchodzącej nowej epoki świata.

Słowa kluczowe: Adyar, Madras, Towarzystwo Teozoficzne, Helena Bławatska, drzewo banyan, utopia, perenializm 